\title{
Freudian Doubles: Psychoanalysis and Governance in Colonial India
}

\author{
Shiva Kumar Srinivasan \\ Behavioral Sciences, International Institute of Planning and Management, Chennai, India
}

\begin{abstract}
What was the relationship between discourses like anthropology and psychoanalysis in Colonial India? Would it be correct to maintain that these discourses colluded with the colonial project of the British Raj? This paper argues that while it would appear that there were some instances of what appear to be collusion, a closer examination of the evidence would determine that such instances were few and far between. Most of the theories of psychoanalysis; the evidence presented in the Girindrashekar Bose-Sigmund Freud correspondence of 1921-1931; and Christiane Hartnack's pioneering study of the deployment of psychoanalysis in colonial India actually have more of a clinical - than a political oran ideological orientation. It is however easy to come to the wrong conclusions if we don't recognize that the demographic representation of Indian and British patients at Ranchi and Calcutta were different from those of Freud's clinic at Vienna. Most of the patients in Indian clinics were obsessional or psychotic males while Freud's patients were mainly female hysterics. Any attempt to draw a theory of colonial subjectivity on the basis of such patients must recognize these socio-cultural and demographic differences. It must alsoexamine why the Bose-Freud correspondence did not make sufficient headway towards any fundamental revisions in Freudian meta-psychology. This paper prepares the reader to appreciate these theoretical problems by first thinking through the relevance of the work of the psychoanalysts, Sigmund Freud and Jacques Lacan, in the context of psychoanalytic anthropology. It does so by explaining the importance of the colonial imaginary in structuring the intersubjective dynamics of the colonizer and colonized. It argues that the colonial imaginary is not to be conflated with the colonial imagination, and that the effects of the imaginary are very real indeed. It is therefore important to differentiate between the terms 'aggressivity' and 'aggression' in invoking the Lacanian notion of the imaginary order to explain the inter-subjective dynamics of colonial relations. The propensity to overdo the fear of collusion stems precisely from conflating the notion of aggressivity with that of aggression, and in not differentiating between the scope of different forms of historical explanation.
\end{abstract}

Keywords:Aggression, Aggressivity,Anthropology, Colonialism, Governance, Imaginary, Oedipus, Real, Symbolic

\section{Introduction}

This paper will attempt both a basic exposition and a theoretical application of Jacques Lacan's notion of the 'imaginary order' to the relationship between the institutional deployment of psychoanalysis and the forms of governance that were prevalent in colonial India. This analysis should however not be construed as a foray in the empirical history of psychoanalysis. It is instead an attempt to juxtapose certain psychoanalytic concerns that are characteristic of the work of the French psychoanalyst Jacques Marie Émile Lacan within the traditional themes of psychoanalytic anthropology and colonial relations during the British Raj. The term, 'imaginary order', for instance, is used in this paper as that which is constituted in the human subject through the so-called 'mirror stage' in Lacanian theory; which, JacquesLacan defines as, 'a drama whose internal thrust is precipitated from insufficiency to anticipation - and which manufactures for the subject, caught up in the lure of spatial identification, the succession of phantasies that extends from a fragmented body image to a form of its totality that I shall call orthopedic - and lastly, to the assumption of the armor of an alienating identity, which will mark with its rigid structure the subject's entire mental development. Thus, to break out of the circle of the Innenwelt into the Umwelt generates the inexhaustible quadrature of the ego's verifications' (Lacan, 1949, 1977). The imaginary orderthen encompasses all those psychic activities and phantasies that govern the libidinal circuit between the human subject and its counterparts, competitors, friends, and rivals; including, most famously, the so-called 'double', which is one of the best possible instantiations of the imaginary relation. These imaginary relations are simultaneously constituted by both 'erotic attraction' and 'aggressive tension', and are therefore easily affected by forms of physical, emotional, and material resemblance between a subject and an object, or between a subject and its others. They become an important form of ideological interpellation insociety asa whole and not just in terms of colonial relations; though, admittedly, the colonial situation exacerbates these problems in terms of the spatial distinction between those inside and those outside the colonial imaginary (Evans, 1996a; Laplanche and Pontalis, 1973, 1988; Elliott, 1996; Pile, 1998; Said, 1999). The 
imaginary however is not just a stage in childhood that an infant goes through (i.e. it is not reducible to the mirror stage). Itis instead described as a constitutive order of all human thought that is 'deceptive' insofar as it limits the subject to the imaginary order of 'misrecognition', rather than help the subject to understand how he relates, or should relate, to the symbolic order of social relations. In the Lacanian model of subjectivity, the subject is constituted through the orders of the real, the imaginary, and the symbolic. The imaginary in this model is structured not only by an irreducible form of narcissism, but also by endemic forms of aggressivity in the psyche (Freud, 1914; Hall, 2004). It is possible to demonstrate how a 'liberatory' discourse like psychoanalysis began to serve simultaneously as both a tool of colonization and as a tool of emancipatory critique in colonial India since attempts to apply psychoanalysis in a colonial situation were themselves mediated and distorted by the order of imaginary relations. The colonial enactment of this double function of psychoanalysis in colonial Bengal inspired an interesting correspondence between Sigmund Freud (the founder of psychoanalysis) and Girindrashekar Bose (the founder of the Indian Psychoanalytic Society at Calcutta) on the so-called 'universality of the Oedipus complex'; but it did not lead to any important revisions of Freudian meta-psychology on this or any other topic.

Freud and Bose were using an empirical model of the Oedipus complex rather than the structural model that we associate with the French Freudians (who borrow their notion of kinship structure from the structural anthropology of Claude Lévi-Strauss); and therefore wound up talking past each other, or lost the thread of their argument in the socio-cultural variations of the Oedipus complex. It was not clear whether Bose's clinical data was compelling enough to justify a revision of Freudian meta-psychology that early in the history of psychoanalysis (Bose, 1929, 1999; Bose, 1964, 1999; Boyne, 1996; Hartnack, 2001a; Jones, 1948; Nandy, 1995a; Shalvey, 1970; Ramanujan, 1999; Courtright, 1999; Obeyesekere, 1999). Another reason relates to the fact that both anthropology and psychoanalysis were discourses of subjectivity that were struggling to articulate the Oedipus complex by invoking an empirical model of the subject rather than workwith a linguistic model based on kinship structure. Freud was not personally acquainted (unlike Lacan) with either structural linguistics or with structural anthropology, and was under the impression that the main task of psychoanalytic anthropology would be to verify the 'ubiquity of the Oedipus complex' in the forms that he had identified in his clinical work throughout the world rather than focus on the incest taboo as the relevant universal - even though he had anticipated the 'horror of incest'as the affective equivalent of the incest taboo in his studies on the totem and th taboo(Johnson and Price-Williams, 1996; Freud, 1913a, 1990a).A great deal of Freudian anthropology, needless to say, is actually preoccupied with whether it is the father or the uncle who provides a child with libidinal distance from the mother within a model of oedipal individuation. What is obviously missing in Freudian anthropology is the abstract notion of the paternal 'function' as such since anthropologists were preoccupied with a substantive notion of the father; or the substantive notion of the uncle, rather than with the prohibitive function that all fathers and uncles have in common - i.e. the enforcement of the incest taboo on the next generation (LeVine, 1996; Lévi-Strauss 1949, 1969; Geertz, 1973).I argue that any attempt to unravel this imaginary knot in psychoanalytic anthropology of the Oedipus complex must proceed by delineating exactly what Jacques Lacan meant by the order of the imaginary. A great deal of misunderstanding has been perpetrated through incorrectrenditions of psychoanalysis around the mythical dramaturgy of the mirror stage. These theoretical accounts invoke only a notion of imaginary narcissism without an understanding of the part played by imaginaryaggressivity. The missed encounter between Freud and Bose will be examined in the form of an interpretation of the Bose-Freud correspondence; which, in turn, will be situated within the context of the pioneering work done by the historian Christiane Hartnack in this area (Hartnack, 2001b). The main arguments in Hartnack's book will be invoked as an enactment of the imaginary dialectic between narcissism and aggressivity that she sets out to deconstruct in her project to understand the relationship between psychoanalysis and governance in colonial India.

\section{The Colonial Imaginary is Real}

Before proceeding further, however, it is important to note that the imaginary should not be conflated with the idea of the colonial or literary 'imagination', or the simplistic assumption that the function of the imaginary can be discounted in human relations if we just inform everybody concerned that it can be a source of distortion. Such an approach would be a fundamental misunderstanding of what Lacan means by the imaginary (Elliott, 1992; Jenks, 1995). In the Lacanian doctrine, the imaginary is not something that is merely 'imagined'as opposed to something that exists. Indeed, for Lacan, the imaginary is very real. It is therefore important to not essentialize the imaginary as just imaginary, but understand that the imaginary has effects of the real on the subject. That is, the imaginary has effects of being on the subject and is mainly concerned with the realm of 'dual relations'. In the specific instance of the colonial enterprise, for instance, the colonizer would like to see an ideal reflection of himself through the gaze of his imaginary counterpart. The counterpart is asked to occupy the role of the enabling gaze in which the colonizer can affirm his own sense of identity as masculine and dominant. But this affirmation of the colonizer's identity is much more problematic than either he or his counterpart realize, since it does not suffice for the idealizing gaze of the counterpart to be a weak affirmation of the 
colonizer's identity - the colonizer is after all not politically naïve. The colonizer can only function for a gaze that is intelligent enough to affirm his identity as masculine, dominant, and superior, and not just vaguely better. The gaze of the colonized must instead be a strong affirmation of the fact that the colonizer's identity is intrinsically superior. In other words, the gaze of the colonized must be at the threshold of taking on the imaginary function of the double. It is at this threshold of the intersubjective dynamics between the colonizer and the colonized (or, more structurally, if we wanted to abstract from the colonial situation - between the subject and its double or counterparts - that the imaginary takes on the properties of the real). If this were not the case, the intersubjective dynamics will lack the libidinal charge that will make the colonial encounter exciting enough for both the parties. The counterpart however cannot take on the function of the double without inadvertently reminding the colonizer that his intrinsic superiority is only historically incidental and not essential to the colonial encounter. Insofar as the double is at the locus of imaginary alienation and death, it is also the site of aggressivity. This problem is related to the psychoanalytic proverb that when a subject meets its double, it is time to die. The enabling gaze that the colonizer seeks in the field of action that will affirm his masculinity is impossible to attain historically unless the colonized is willing to retreat from not only the function of the double (the imaginary as real), but also from that of the counterpart (the real as the imaginary). This symbolic retreat will however restructure the libidinal circuit in which the colonizer seeks recognition for his dominant masculine identity from the colonized subject. This will trigger off the aggressivity of the colonized subject, and not just the commonplace political aggression that nationalist historians are fond of chronicling through their staple narratives of massacres. Unless we move therefore from a model of commonplace colonial aggression to thinking through the dimensions of imaginary aggressivity, as understood in the Lacanian doctrine, we will not be able to situate the role that psychoanalysis can play in unpacking the imperial politics of recognition in the colonial field. This differentiation will also make it possible to understand that the order of the imaginary is a much more complex entity than the opposition between the imaginary and the symbolic implies in studies of colonial identity, since the imaginary is implicated in the real, and is not an avoidable form of distortion that has marred the history of colonial representations (Jan Mohamed, 1995).

\section{The Imaginary and the Symbolic}

The main difference between the argument in Mohamed's paper and mine is that he is preoccupied with how fictional representations of colonial predicaments in the history of the novel, for instance, can be classified under the opposition of the imaginary and the symbolic. He then situates the imaginary as necessarily implicated in the negative aspects of the colonial enterprise, and the symbolic as a more liberal, sympathetic, opening up of syncretic possibilities even while he recognizes that invoking too rigid a notion of the imaginarysymbolic opposition can be misleading since these are differences of degree rather than differences of kind. So, for instance, the white writer who is sympathetic to the plight of the colonized peoples, struggles with the impossibility of eradicating his own subjective position in order to offer the colonized their place in history. It is at the moment when the colonizer realizes the structural impossibility of removing himself from history that he encounters the real of imaginary aggressivity. Hence, we must move from merely noting that a Manichean aesthetics is at play in colonial representations and colonial relations to ask what sort of a constitutive role can be attributed to the problem of aggressivity in human relations as a whole within theories of subjectivity that are related to psychoanalysis. That is why it is important to invoke both Lacan's work on the mirror stage and his work on aggressivity to situate the part played by the imaginary in the Lacanian model of cognition. By taking this stance on aggressivity (as opposed to commonplace aggression), it can be argued that'Lacan is simply restating Freud's concept of ambivalence (the interdependence of love and hate), which Lacan regards as one of the fundamental discoveries of psychoanalysis' (Evans, 1996b). This aggressivity, which takes the form of ambivalence or existential irritability, is at the heart of both the Oedipal relation and the colonial encounter since both the infant and the colonial subject must learn to find their way vis-à-vis the desire of the Other. In fact, the colonial imaginary itself is based on the assumption that the colonized is in the locus of a child, and needs to grow up before he can assume his subjectivity, responsibilities, and obligations, as a free citizen.

\section{Aggressivity is not Aggression}

The term, 'aggressivity', in Lacan does not carry the same connotations as the term, 'aggression', in politics and history. In the Lacanian doctrine, it is the imaginary forms of aggressivity that lead to political forms of aggression. Historians who are preoccupied with narratives of anti-Semitism, massacre, and genocide; including those who apply psychoanalysis to study historical figures, are mainly acquainted with traditional forms of aggression and not with the Lacanian notion of aggressivity (Wolman, 1971; Roth, 1997). The main advantage of invoking the Lacanian model of the imaginary is that it will help us to think throughthe intersubjective dimensions of colonial relations and the part played in it by aggressivity; which is constituted by a form of structural or existential irritability, making it difficult to invoke a simplistic model of either political emancipation or colonial emancipation (Laclau, 1996; Stavrakakis, 1999). Even readers of Lacan forget to invoke his work on aggressivity and get fixated instead on the mirror stage. But, it is not possible to understand 
the implications of the mirror stage without reading Lacan's paper on aggressivity since the mirror stage is preoccupied with anticipatory forms of narcissism, without necessarily explaining what happens when the subject's identity or masculinity is denied recognition in a symbolic realm. This is even more true for the colonizer, as opposed to the commonplace subject of analysis, since the libidinal economy of the colonial enterprise is preoccupied with precisely these forms of the imaginary quest for a masculine identity and domination; and if denied these forms of affirmation, it will activate the death instinct of the colonizer; which Lacan defines as the 'aporia' that can be situated 'at the heart of the notion of aggressivity, the importance of whose role in the economy of the psyche we are only just beginning to realize' (Lacan, 1948, 1977). What Lacan does then is to relate the function of the death instinct within theories of aggressivity, rather than within theories of aggression, as is usually the case (Lorenz, 1974). It is precisely the conflation of these categories that made it difficult to make sense of the horrendous number of deaths during the world wars even when it became commonplace to blame the Freudian death instinct, or the existential fear of freedom, for what went wrong in Hitler's Europe and elsewhere during the war years(Fromm, 1941, 1994).

\section{Aggressivity in Colonial Psychoanalysis}

What is the extent to which psychoanalysis was itself implicated in forms of aggressivity in colonial India? In other words, by asking how the affective mechanisms that constitute the notion of the subject in psychoanalysis is implicated in the transfer of epistemic and political authority from the colonizer to the colonized, we can introduce a new way of thinking about the parallels between the anthropological and psychoanalytic approaches to the basic forms of colonial subjectivity. This problem is not reducible to just Freudian psychoanalysis in countries like India, which had not attained independence in Freud's lifetime, but is a structural one that Lacan poses quite spontaneously in the context of his project of a 'return to Freud'. Hence, I will argue in this paper that Hartnack's pioneering work on the relationship between psychoanalysis and governance in colonial India deserves a meta-psychological reading even though the Bose-Freud correspondence of 1921-1931 did not lead to any revisions in Freudian meta-psychology. This approach will ensure that its significance is not restricted to students of Indian history, but is made known to scholars in the Freudian field and colonial studies. The meta-psychological problem relates quite simply to the relationship between the Freudian notion of the unconscious and the anthropological notion of the unconscious, and the ways in which they intersect in the construction of colonial identity. This problem is not only represented in, but also embodied by, the Oedipus complex - albeit through the colonial imaginary. This is the problem that Lacan himself addressed in a different context - when he wrote that 'I posed the following question: the functioning of "Primitive Thinking" (la Pensée sauvage), which Lévi-Strauss places at the basis of the statutes of society, is one unconscious, but is it enough to accommodate the unconscious as such? And if it is able to do so, does it accommodate the Freudian unconscious? (Lacan, 1973a, 1977a).The crux of the matter is that by introducing a theory of the unconscious, via structural anthropology as the 'discourse of the Other', psychoanalysis makes the incest taboo the irascible knot in the libidinal economy of kinship. It is however not sufficient to merely point to this intervention as a way of differentiating between nature and culture since it becomes necessary to examine the particular forms of psychopathology that this existential task imposes on the human subject. In other words, an understanding of the structural dimensions of the incest taboo, or the structural dimensions of this problem as a rite of passage through the Oedipus complex, does not make the patient's suffering from a failure of repression go away. This is because by pointing out the psychopathological underpinnings of the Oedipus complex, and by elevating it to a universal rite of passage to subjectivity, Freud made it impossible for anthropology to fence its empirical findings, or theoretical conclusions, as necessarily intrinsic to 'cold' societies and thereby endorse the normalization of psychic defenses that we associate with the project of modernity in 'hot' societies. Kirschner points out, for instance, that 'Freud as well as many post-Freudians have tended at times to blur the boundaries between normal and abnormal, natural and civilized, and even rational and irrational. All forms of psychic organization are to be understood as different solutions to the same inescapable and tragic situation (the vicissitudes of Oedipus, or of separation-individuation and disillusionment). Analytic perspectives stress the inescapability of that situation, and the imperfect and compromised nature of all possible solutions. Certainly few who call themselves analytic would assert that there is an absolute or ideal normality' (Kirschner, 2001). The psychoanalytic take on anthropology makes it difficult then to delimit the Oedipal problematic to the safe confines of Greek mythology or Greek tragedy. Such a confinement ideologically means that the Oedipus myth would merely remain the mytho-poetic currency of literary representations while the more technocratic disciplines would remain immune to the desire of the Other. But, in fact, there are good reasons to believe that the Oedipus complex does not necessarily subsume the Oedipus myth, but only constitutes one of its betterknown articulations in Freudian psychoanalysis in a way that can rival its original deployment in ancient Greek literature (Goux, 1994; Goodrich, 1995). So, irrespective of whether we seek a clinical or a cultural verification of Oedipus, the relationship between psychoanalysis and anthropology has taken a turn that even Freud could not have anticipated (Kakar, 1995, 2001). It is important to understand this clearly since it is by no means obvious that Freud was interested in anthropology as an end in itself. It appears that Freud's main interest in 
anthropology - apart from examining the universality of the Oedipus complex - relates to the analogy that he posits between the psychic lives of savages and neurotics; we can of course add the colonial subject to the menagerie of the afflicted (Nandy, 1995b). Freud's interest also relates to his realization that ethnographic representations in anthropology cannot help but externalize the fantasy structure of a neurosis. Since these fantasy structures had an element of scandal, it was convenient for Freud to not only point out, whenever possible, that not only are these structures always already in circulation, but that these fantasies are much more common than they were thought to be; and that furthermore the anthropological discovery of 'savage thought' lives on in the unconscious (Freud, 1913, 1990).

\section{Here and There}

The persistence of 'savage' thought - as the insistence of the unconscious - made it necessary for the psychoanalyst, like the anthropologist or even the colonizer, to work out a relationship between what is 'here' and what is 'there'. 'There', needless to say, is the anthropological object of representation and 'here' is thelinguistic locus of representation (Geertz, 1988a; Geertz, 1988b). The relationship between here and there is mediated by an ethics that is important in the Kantian world-view. What is at stake however is not just the ethics of representation; but also the problem of 'being' since what is at stake is the Kantian categorical imperative. Can the other out there be treated only as an object? Or can it be imbued with subjectivity, with being, in its own turn? Can the object in the locus of the Other betreated asan end in itself - rather than as a means to an end? Anthropology has traditionally been unable to resolve this question of being because it has consequences for the act of representation. If the Other is reduced to an object of representation, the epistemic subject of anthropology is damned as unethical, as being 'colonial' in its orientation; if the Other is elevated to the status of a knowing subject, the anthropologist is accused of having 'gone native'. In the former scenario, the anthropologist is less than human since he is being political; in the latter, he is less than a social scientist because he is being romantic. English anthropologists are thought to be like the former; French anthropologists, like the latter. What then is the main difference between the anthropologist and the psychoanalyst? How do we connect this difference to the problem of a colonial identity that oscillates in an imaginary economy between the counterpart and the double? If we look at the opposition between the terms 'there' and 'here', i.e., as mentioned above, between the object of representation and the locus of representation, the answer that emerges is that the anthropologist must go there even though the native doesn't seek him; the native is self-sufficient despite his exclusion from history. It is the anthropologist who pursues his object of study like a colonial explorer. The psychoanalyst, on the contrary, does not have to go anywhere since the unconscious is not a place though it is common enough to find that it is described as a place through the invocation of spatial metaphors. The unconscious, as Freudians remind us, is actually a psychic function and not a place. Hence Lacan's celebration of the Freudian ethic of truth - in pursuing the discourse of the hysteric - despite the residual elements of the spatial in his elaboration of the unconscious in Seminar XI, where he writes that 'the status of the unconscious which...is so fragile on the ontic plane, is ethical. In his thirst for truth, Freud says, Whatever it is, I must go there, because, somewhere, this unconscious reveals itself (Lacan, 1973b, 1997b). The historical or the philosophical project of modernity demanded a repression of the anthropological subject and an externalization of its themes in the Other. But insofar as there are continuities of social functions in the anthropological pretext, there is no such thing as a complete transition to a historical space that is shorn of all ethnic residues. The fantasy of the cosmopolitan subject in Kant then needs a necessary detour through the space of the ethnic since there cannot be a model of the subject that is not related to some form ofbodilyjouissance.

\section{The Kantian Subject}

The quest for perpetual peace in the Kantian model of the subject necessitates a movement away from the pathology of jouissance that is embodied in the problem of the ethnic to a transcendental notion of the subject that is emptied of all empirical content (Kant, 1795, 1983). The emergence of Kant's philosophical anthropology then is dependent quite directly on a repudiation of the Freudian unconscious, of its pathological content, which is a site of how desire emerges through the mediation of kinship structures as the desire of the Other. But this does not mean that the Freudian project has nothing to do with the Kantian since Freud cannot be read outside the epistemic space of the Enlightenment. What else is the Freudian project but an attempt to implicate the Kantian coordinates of space and time, of the epistemic a priori, in the libidinal body of the subject? Is a Freudian metapsychology of the unconscious even conceivable if Kant had not taught the psychoanalysts how to construct 'conditions of possibility' arguments even if it is only the Kantian subject that they seek to hystericize (Brook, 2002, 2003)? The basic tension in the Freudian model between the unconscious that is outside space and time; but which is nonetheless modelled on language, continues in the Lacanian model as well. Lacan's work in the 1950s relates quite directly to the problem of the Symbolic Other that he borrows from his reading of Lévi-Strauss. The very definition of a neurosis is that it is as an 'appeal to the Other' (Lacan, $1953,1979)$. The Other, which is defined as the locus of language, is identified most importantly with the modalities of jouissance that are permissible in a symbolic system. So, while for Lévi-Strauss, the specific form 
of the Oedipus myth that is deployed in psychoanalysis is just one of a series of permutations and combinations; for Lacan, it is almost the same as the process of socialization. While Lacan's early work on the imaginary in the 1930's was inspired by ethology; his later work in the 1950's borrows from ethnology. Ethnology is the site where the universality of the incest taboo can be most effectively demonstrated outside the space of modernity. Since the birth of the analytic clinic is itself implicated in the problem of modernity, the turn to ethnology makes possible an inquiry into the conditions of possibility of the symbolic of which a kinship system would be a good example in structural anthropology (Lévi-Strauss, 1983, 1985). It helps psychoanalysis to move away from the empirical critique of the universality of the Oedipus complex in Freudian anthropology by addressing the familial complex embodied in a kinship system as a whole. Freud's engagement with anthropology, as discussed above, is found in his studies on the totem and the taboo (Freud, 1913c, 1990c). While Freud was not an anthropologist by training, and did not do any fieldwork himself, his analytic methodology revolves around a simple insight. The essence of his insight is that insofar as the formations of the unconscious can be stated as the minimal universals of structural anthropology, they are formal representations of the libidinal turbulence that kinship systems regulate; psychoanalysis then becomes a kind of fieldwork. The native, the indigenous subject, did not have to be sought out in the field. He presented himself of his own volition to the analyst in a manner that reminds us of the adage that psychoanalysis is not completely external tothelure of shamanism (Kakar, 1982, 1998). Though the Freudian psychoanalyst may not seek the native proactively in the course of his daily practice; we need but look at the parallels between the deployment of anthropology and psychoanalysis in colonial India. Since these discourses were both tools of understanding and tools of governance, they came under pressure to be politically correct in the context of the colonial enterprise. How did anthropologists and psychoanalysts withstand these pressures? What can we learn by examining their attitudes to the theories that gave them their sense of professional identity?

\section{Freud as a Colonial Officer}

Christiane Hartnack foregrounds precisely these kinds of questions in terms of this double function. Theories in anthropology and psychoanalysis are not inherently liberatory or repressive; what really matters is how they are deployed, and whether the political environment is conducive to the dissemination of these theories, and their applications. In other words, Hartnack's study can be read as a continuation (in the context of the Indian subcontinent) of Franz Fanon's pioneering work on the psychopathology of colonialism, and the appropriation of these themes subsequently in postcolonial theory (Fanon, 1952, 1967; Gates, 1991). Should Hartnack begin her account of psychoanalysis in colonial India with an examination of how the British deployed psychoanalysis to pathologize the resistance to colonization? Was it right to equate the colonial subject to a child that has to be brought up (Nandy, 1983)? Or should she instead examine how psychoanalysts based in colonial Bengal were able to critique colonialism by using psychoanalysis? Are there any grounds to believe that the orthodox form of the Oedipus complex was an incursion of colonial anthropology in the guise of Freudian metapsychology? These then are some of the important questions that haunt Hartnack's study. While not much is actually known about what Freud really thought on these themes, Hartnack's conclusion is that Freud comes across as hegemonic in his attitude to Indians and that Freud was mainly interested in India as an easy conquest given his preoccupation with the image of 'conquistadors' in his fantasy life (Schimmel, 2014). One of the more interesting revelations of Hartnack's study is that Freud liked being portrayed as a British colonial officer. On receiving a statuette of the Hindu god Vishnu from Girindrashekar Bose, Freud couldn't help but confess to Bose that 'the statuette is charming; I gave it the place of honor on my desk. As long as I can enjoy life it will recall to my mind the progress of psychoanalysis, the proud conquests it has made in foreign countries' (Freud cited in Hartnack, 2001c; Srinivasan, 1999). Hartnack argues that what the statue symbolizes is Freud's need for a conquest, but that doesn't explain why Freud must admit severe revisions in analytic theory in order to make a success of every correspondence with disciples from around the world. It is therefore important to not take the Bose-Freud correspondence out of context, and ask instead how much of Freudian meta-psychology as a whole was revised due to the wide-ranging correspondence that Freud had with analytic societies from around the world to get a more proportionate understanding of what might have gone right or gone wrong with the Bose-Freud correspondence (Hartnack, 1999; Parsons, 1999). What is important to remember here is that Freud's personal fantasies of conquest do not mean that psychoanalysis is necessarily hegemonic as a discourse. Freud might have nursed fantasies that are not politically correct by today's standards, but that does not necessarily detract from the usefulness of his theory. In any case, Freud's fantasy of conquest remained imaginary since the psychoanalytic 'internationale' did not shape up in the way that he envisaged. The fantasy of a Freudian Orient turned out to be precisely that - a fantasy since psychoanalysis did not take root in India in the way in which it did in many other parts of the world. Hartnack tries to explain why this is the case. The main argument that she makes is that psychoanalysis unwittingly became an accomplice of the colonial project; it thereby undermined its credibility to some extent. What are the arguments that Hartnack invokes in support of her thesis? The next section of this paper will examine the Bose-Freud correspondence to 
see whether Hartnack's arguments justify her conclusions and whether it is possible to 'recuperate' psychoanalysis from the colonial context in which it was introduced in colonial India.

\section{The Bose-Freud Correspondence: (1921-37)}

The main source of disagreement between Bose and Freud on the nature of the Oedipus complex relates to the fact that they were working with different types of clinical data. So, for instance, Freud's patients were mostly female hysterics while Bose's patients were male obsessionals. Hartnack points out that Bose had difficulty in corresponding with Freud as an equal, but it is not clear why Bose could even imagine that he was an equal given that he was just starting out on a clinical career whereas Freud was not just another psychoanalyst; he was the founder of the analytic movement. In the absence of a full-fledged psychoanalytic movement in India; it is not clear what exactly Bose's contribution to meta-psychology could be such that he could either expect to be received as an equal by Freud, or expect revisions within mainline Freudian theory in response to the fact that he was seeing more obsessionals than hysterics in his clinic. The Bose-Freud correspondence began in 1921 when Bose mailed a copy of his work on the The Concept of Repression, which was his doctoral dissertation that he had submitted to the University of Calcutta. Though the letter is not dated, we can infer that it must have been mailed in 1921 since Freud wrote back on May 29 of that year. Bose's dissertation was accompanied by a statement of interest in psychoanalysis. In his reply of May 29, Freud testified to the correctness of Bose's 'views and the good sense appearing in it'. After expressing surprise that psychoanalysis should have met with interest and recognition in a far-off country like India, Freud pointed out that Bose's psychoanalytic method used deductive reason whereas his own was empirical. This is strictly speaking not true since the main problem that many theorists have with Freudian psychoanalysis is that it is not empirical enough to be termed scientific - let alone a science (Crews, 1998; Forrester, 1997). But, nonetheless, insofar as Freud's espoused theory was empiricism, it was an inoffensive way of not getting too close to Bose. It would not be too far-fetched to say that Bose would have had no differences with Freud if his method was really deductive since the question of him seeing more obsessionals, and Freud seeing more hysterics, would not have been a problem for either. The reader should not be surprised at seeing these analysts transferentially project upon each other in their correspondence. Freud also expressed the hope that the translations of psychoanalytic articles from the German that were forthcoming in the International Journal of Psychoanalysis would help Bose with his future work.

\section{The Letters of 1921}

The very first round of letters, exchanged in 1921, invoke the order of the imaginary though the actual contents seem routine and unremarkable. This invocation will proceed through the transferential and countertransferential demands for recognition on the part of both Bose and Freud. Bose, it might be said, is first of all asking for recognition for the work that went into his doctoral dissertation at Calcutta, but is careful enough to write to Freud from the locus of a supplicant. Bose doesn't fail to point out that Freud was a household name in Calcutta and that psychoanalysis had admirers all over India. Freud's universal renown then serves as the general context in which Bose hopes to open a dialogue (as he will proceed to do in the correspondence) on the controversial status of the Oedipus complex, and its relationship to the ubiquity of the castration complex in psychoanalytic theory. While Freud is quick in his reply to recognize the innovativeness of Bose's work, he can't help but notice that psychoanalysis has made some headway in India without any conscious effort on his part. It didn't really cost Freud anything to give Bose some recognition if the latter positioned himself as an admirer. Freud's generosity was but small change since not much was at stake at the moment and Bose's letters were technically nothing more than fan-mail. But since Freud had a world-wide correspondence with admirers of psychoanalysis, he could not have failed to recognize the transferential complexities of fan-mail as a genre. This is all the more so since Bose's correspondence and transference are mediated in a colonial context; which, by itself, was a complicating factor. The only stratagem that Freud could think up to keep the correspondence and the transference in good repair was to point out a methodological difference; Freud felt that he was scientific while Bose was speculative. In the second round of correspondence of 1921, Bose once again invokes the imaginary but rationalized doing so - as most Indians do - by asking Freud for a photograph. It is not uncommon for Indians to make this demand since Indians believe in the concept of 'darshan'; which can be defined as a transferential spectacle of the figure of the Guru in Indian fantasy structure whose very presence can cure the patient (Kakar, 1985; Kakar, 1996a; Kakar, 1996b; Kakar, 2008). Again, given the novelty of psychoanalysis as a clinical method and the scope of the Freudian achievement, this demand does not seem misplaced until we notice that the imaginary cloaks the real demand. Bose's real goal in writing the letter is to find out if his book on repression will do well in a German translation. Clearly, there is a lot of difference between asking Freud for translations of psychoanalytic texts from the German and asking whether there was a market for Bose's own work in German. Bose, of course, doesn't take responsibility for this demand. Instead, Bose attributes this demand to his literary agent: This sort of broad-based demand that seeks both recognition and tips on marketing is precisely the sort of move that is designed to endanger the correspondence; especially 
when Bose expects Freud to buy the silly excuse that he wasn't too well informed about the publishing industry in Austria and Germany. Writing back on August 3, 1921 from the mountains of Badgastein, where he was on a holiday, Freud replies very briefly that he won't be back in Vienna until October 1, and that he is not currently in possession of either Bose's book or his own photograph, but that the editor of the International Journal of Psychoanalysis would send Bose the information requested. October 1 seems to have passed without event; Bose, after cooling his heels till November 24, finally decides to broach the issue again in the last of the letters that he would write to Freud in 1921. Bose also has real developments to report to Freud. Bose's correspondence with Ernest Jones had yielded practical suggestions on how an association of psychoanalysis could be started in India, and the draft rules in order to do so were being drawn up. While assuring Freud that even the vernacular press had taken a fancy to psychoanalysis, he included a question paper on 'Mental Pathology' that he had helped to design for MA and MSc students of psychology at the University of Calcutta. Bose wrote to Freud again on January 26, 1922 with a pencil sketch drawn from the imagination by J. Sen, an Indian artist, on what Freud 'ought to look like', along with an invitation to visit India in order to deliver lectures at the University of Calcutta. Freud wrote back on February 20 with his photograph and a blurb for the latter's book on repression. Here, again, Freud emphasizes that psychoanalysis had not yet attained the theoretical levels that Bose was attributing to it. Bose and Freud are preoccupied with what Freud and psychoanalysis ought to look like and be like. The failure of the correspondence, or the misunderstandings that it was subject to, had to do with the problem of the imaginary. The expectations on both sides pertained to what ought to be the case instead of what in fact was the case; these transferential distortions can be read allegorically then as symptomatic of the problem of epistemic authority in colonial situations that would have made any revisions to Freudian theory problematic even if Freud were sympathetic to Bose's innovations.

\section{The Letters of 1922}

Freud's response to Sen's line sketch of him and Bose's response to Freud's photograph are our next clues. On March 1, 1922, Freud writes that 'the imaginative portrait you sent me is very nice indeed, far too nice for the subject. You will soon have occasion to confront it with the photo and see that the artist did not take into account certain racial characters'. One wishes then that the editor of the Bose-Freud correspondence had included the photo and the sketch so that the reader can make up his mind on what aspects of Freud's features were missing in Sen's portrait. It was not just the representation that would be problematic, but Bose's invitation to Freud to visit India as well. As an afterthought, Freud decided to invite Bose to Europe as he himself was too old to travel. In his reply to Freud, Bose expresses pleasure at receiving Freud's photograph: 'Your portrait has been very acceptable to a wide circle of friends'. It isn't quite clear what the connotations of the term 'acceptable' are in this case. It probably means that it served the function of darshan by consolidating a group identity. Bose thanked Freud for the blurb and admitted the possibility of taking up the latter's invitation to visit Europe. Bose is also finally able to speak up on behalf of a psychoanalytic society that had been set up under the aegis of Ernest Jones's advice and was affiliated to the international society. Freud's reply of October 27, 1922 is marked with less anxiety about what his Indian followers might demand since their relationship has become more formal. Furthermore, as the editor for the official psychoanalytic journals, Freud was in a position to publish Bose's name on the cover of both the German and English editions as the representative of the Indian psychoanalytic movement. Freud seems perfectly sincere when he invited Bose to contribute to these psychoanalytic journals. In his reply of November 23, 1922, Bose informed Freud that Ernest Jones had requested him to be the associate editor from India of the international journals - a task that Bose found gratifying despite his apprehensions about not knowing German. Bose signed off by wishing the not-so-Jewish Freud a Merry Christmas and a Happy New Year to which Freud wrote back promptly on December 28, wishing Bose a Happy New Year as well and as much success in his work as he 'deserves!'

\section{The Letters of 1929-1931}

The Bose-Freud correspondence moves beyond pleasantries and picks up momentum six years later in 1929; when, in reply to a letter from Freud, Bose wrote on January 31, 1929, with a list of enclosures of the work that he had published in psychoanalysis. Bose's work, comprising a book on the theory of dreams in Bengali, and thirteen articles comprising five popular and eight technical pieces, were meant to be read in a particular sequence. Bose also drew Freud's attention to his paper on the Oedipus wish in which he had departed from Freudian orthodoxy. In his reply of March 9, 1929, Freud pointed out that Bose's theory of the opposite wish seemed to stress a formal rather than a dynamic element, and that Bose seemed to under-emphasize the importance of castration anxiety. He also called attention to a mistake in Bose's paper where he describes Oedipus as killing himself which was not the case. The point in contention was on the desire to be female. Freud writes that he had 'never denied the connection of the castration wish with the wish to be a female, or that of the fear with the horror of becoming a female'. In his reply of April 11, 1929, Bose writes rather disarmingly that he did not expect Freud to off-hand buy into his interpretation of the Oedipus complex, or deny the importance of the castration complex, in the case of European patients. Though the castration complex is common in Indian 
society, it did not seem to give rise to psychopathological consequences since Indian male patients did not severely repress their femininity or their desire to be women; hence, the affinity between the Oedipal mother and the 'maternal deity' in Indian religions (Kakar and Kakar, 2007). Bose also went on to link his theory of the wish (where the subject desires both ' $\mathrm{x}$ ' and its opposite simultaneously) with the problem of the pleasure principle. The essence of his argument is that there is no need to invoke the notion of a repetition compulsion since in a traumatic situation it is something passive in the subject that is at stake. The retroactive attempt to come to terms with a trauma, Bose argued, is nothing but the opposite wish (i.e. the active element) seeking expression in the subject's life so that both the passive and the active elements will remain important (Kakar, 1989, 2001). Writing back on May 12, 1929, Freud wonders how Bose's theory of opposite wishes links to the problem of ambivalence. There is clearly an insinuation here that whatever is valuable in Bose's theory is already available through the notion of ambivalence. There is no record of any theoretical discussion between this period and January, 1933 when Freud resumes an analysis of Bose's revisions to psychoanalytic theory. But, the intervening period was not devoid of event; in 1931, Bose sent Freud an ivory statuette of the Hindu god Vishnu along with 'two copies of a Sanskrit address to you printed on silk and also three copies of the proceedings of the meeting of the Society held on 6th May to celebrate your 75th birthday anniversary'. There were a few letters that were exchanged from 1932 to 1937 between Bose and Freud, but not all of them are relevant to the meta-psychological themes of the correspondence with the exception of the letter that Freud wrote on January 1, 1933 and Bose's reply of February 1, 1933.

\section{Conclusions from the Correspondence}

It is interesting that Bose's main goal was to develop his own psychoanalytic technique that he terms the 'see-saw' method. The see-saw, needless to say, is the essence of the imaginary. In a see-saw, being flows from one person to another as they situate themselves within a transference and a counter-transference. In Bose's metapsychology, the subject see-saws between opposite or even conflicting wishes. It is almost as though Bose was able to anticipate the Lacanian notion of the imaginary in his theory of opposite wishes which Freud himself seems to over-look. While Bose was trying to suture the ontological gap between the subject and the object in order to develop a holistic notion of the ego, Freud's lack of receptivity to the originality of his theory rendered their correspondence no more than a series of friendly exchanges without any consequence to the theories that they were working on. Bose's insistence that Indian patients were more at home with their femininity and did not have deep-rooted fears of castration in the way that Freud's patients did was not really appreciated or understood in Vienna. Freud refused to see that he and Bose could be straddling a see-saw like structure in their correspondence, but he left the correspondence open-ended by stating that while he found Bose's theory different, it did not seem to him that it 'evolved from the study of our pathological material' - this relates to the fact that they were seeing different types of patients. And, furthermore, Freud felt that Bose's approach would not explain the clinical phenomena relating to 'anxiety or the phenomena of repression'. Freud's puts his points across mildly, but it is important to remember that Bose initially approached Freud as an expert on repression. Freud had appreciated his work on repression, but has difficulty in reconciling the Freudian model of repression with the theory of opposite wishes. But Freud does concede that Bose has raised important points which have to be thought-through. As Freud puts it, 'I see that we did neglect the fact of the existence of opposite wishes from the three sources of bisexuality (male and female), ambivalence (love-hate), and the opposition of active-passive. These phenomena have to be worked into our system to make us see what modifications or corrections are necessary and how far we can acquiesce to your ideas'. Bose admits in his reply that he would try to incorporate Freud's points on how the theory of opposite wishes will make sense of anxiety and repression, but it is not clear whether there is closure in their correspondence. The only letter from Freud to Bose was written on October 26, 1937 where they discuss the work of a colleague named S.C. Mitra who was trying to relate abnormal psychology to normal psychology and of which Freud was quite appreciative. The final letter of October 31, 1937 is not from Sigmund Freud; but his daughter Anna, who also comments on Mitra's paper, and expresses a wish to partake of Bose's clinical work in Calcutta.

This is as far as the correspondence went, but its importance is not so much for the fact that it got Freud to rethink his metapsychology (though that was Bose's intent to some extent), but in that by keeping a correspondence going with Freud, Bose became a part of the Freud archive. In 1953, Anna Freud wrote to the Indian Psychoanalytic Society in Calcutta with a request that the Bose-Freud correspondence which was with Bose's widow should be included in the Freud archive; it was subsequently published, and is now considered an important source for historians of psychoanalysis in India. But this is as far as the correspondence could go. It was too early to rethink Freudian metapsychology to make sense of Bose's patients and his interpretation of the opposite wish. Freud was very conscious of the fact that his followers in colonial Bengal were Hindu scholars who had exposure to both Western medicine and psychology. Nevertheless, despite this exposure, he feared that their world-view would not coincide neatly with the Vienna that Freud knew so well. The learned Hindus were neither as patriarchal nor as monotheistic as the central European cultural milieu that characterized the Jewish intellectuals of his time. While the dissemination of psychoanalysis presupposed the availability and impact of 
Western science and psychology in the university system that the bhadralok (the Bengali middle-classes) were educated in, they did not buy into the whole intellectual system that Freudian psychoanalysis represented. In other words, the colonial version of psychoanalysis could not unproblematically piggy-back on the back of the prestige of Western science without any concern for local realities. This is because the revival of learning pulled colonial Bengal in two different directions - that of Western science and liberalism along with a rediscovery of the local culture; which led, not surprisingly, to the desire for both political and intellectual independence. As Hartnack points out, 'Bose also explicitly criticized Freud....and the way he tried to keep the psychoanalytic movement under his control. In his opinion, Freud organized the movement "like a church", and an imaginative portrait of Freud that he sent him in 1922 depicted him as a distinguished British colonial officer'. Subsequently, it was not Bose who represented the Indian psychoanalytic movement abroad; but two British army officers who practiced psychoanalysis in India; they were Lt. Col. Berkeley Hill and Lt. Col. C.D. Daly.

\section{The Punjab Heads}

The main problem that Hill and Daly were confronted with in their practice was the fact that they were not in denial about the complicating factors in the anthropology and psychoanalysis of their time. Their patients in the European Mental Hospital at Ranchi and elsewhere consisted not just of Indians, but also British officials who were unable to legitimize the colonial enterprise. That however was not good enough reason to fall ill. So what was the problem? The problem was that the more educated the British officers were, the more they understood that they could neither legitimize the situation in which they found themselves nor find the political means necessary to solve the problem. This created a moral conflict for them because they were not clear about what they were expected to do. Should they summon the toughness necessary to go ahead with colonialization? Or, should they put up some ethical resistance? If they decide to resist, what would the ambit of official tolerance be for these conscientious objectors to colonial rule? Hill and Daly felt that the mental hospital at Ranchi had been put up to sweep aside those whites who embarrassed the colonial regime with their ethical qualms and conscientious objections. One of the more telling features in Hartnack's book is an incident which recounts, almost paradigmatically, a couple of conscientious Englishmen who meet in a train, probe each other gently for their respective attitudes towards colonialism, and then blast the regime when they felt safe to do so in private, but only to depart like guilty lovers the next morning. Not all the colonial officers were able to put up with the stress induced by these situations - many simply quit and went back to England. Those who did not, fell ill; most of the psychiatric complaints were related to attempts on the part of officers to question the legitimacy of the colonial enterprise. The main fear that British officers suffered from was that if they did not play along, they would be termed 'Punjab Heads' or put away in an Indian asylum for lunatics. A Punjab Head is an officer who lacks the determination to stick it out to the end. The Punjab Heads were retired to a mental asylum because they had ceased to be useful to the colonizers. Any disagreement with the official ideology of colonization would be treated as a form of political dissidence; the concerned officers ran the risk of being treated as insane, or would actually fall ill, because of the conflicts engendered in their psyche. By stripping these agitations of a symbolic purpose that went beyond the narrow confines of the Oedipus complex, psychoanalysis had got off to a false start in India. Even interactions between Englishmen were fraught with political risk; interactions between the colonizers and the natives were, needless to say, few and far between, and simply not worth the risk. Here are a few complicating factors that made it difficult for the Indians to blame the colonizers. Indians often noticed that the way they behaved with members of the lower castes in their own communities was no better than how they were treated by the colonizers. The dominant members of these interactions were so preoccupied with either their fear of familiarity, if they were British; or with their fear of contamination, if they were high-born Hindus; that they could easily rationalize their bad behavior. These problems however should not let us forget the achievements of psychoanalysis in India since psychoanalysis is not a tool of social reform; but a clinical method, which must proceed slowly on a case-by-case basis. It is worth the effort to distinguish rigorously between the doctrinal content of Freudian psychoanalysis as such and its misapplications outside the clinic. While this may seem like an attempt to damn anthropology and recuperate psychoanalysis, a balanced evaluation of Hartnack's arguments will save the reader from a sense of despair at this point.

\section{Calcutta and Ranchi}

Hartnack's book is divided into two parts. The first surveys the work of British psychoanalysts and the second surveys the work of Indian psychoanalysts in colonial Bengal. If Bengal gets an inordinate share of the coverage in this study, it is because the Indian Psychoanalytic Society was founded at 14 Parsibagan Lane in Calcutta. In other words, Indian psychoanalysis owes its vibrancy to the revival of learning during the Bengal Renaissance. The first part of the study engages mainly with the careers of two British psychoanalysts, Owen Berkeley-Hill (1979-1944) and C.D. Daly (1884-1950). Berkeley-Hill had been trained as a doctor at Oxford and had also been educated at Göttingen and Nancy. Hill served out his career in India until his death in 1944, and had served, during World War I, in the East Africa corps. Berkeley-Hill had joined the Indian Medical 
Service (IMS) on an impulse and served in several cantonment hospitals in India including those in Secunderabad, Hyderabad, the Andamans, Madras, and Burma; he was in charge of Mental Asylums in Lahore and Ranchi. He was also a member of the American Psychoanalytic Society and was in contact with Bose. He joined, taught in, and represented the Indian Psychoanalytic Society in conferences in Europe. Hartnack's main focus is on Berkeley-Hill's career as the Head of the European Mental Hospital at Ranchi from 1919 to1934.Berkeley-Hill was given the freedom to make any innovations that he thought was necessary from the provincial governments of Bihar and Bengal since most of his patients belonged to these states. Hill did not publish a formal account of his years at Ranchi but Hartnack attempts to reconstruct his clinical methods from his theoretical papers. The European Mental Hospital had 180 patients at this time; most of the staff was Indian. Amongst the disorders reported were dementia, paranoia, imbecility, melancholia, mania, syphilis, and alcoholism. The forms of treatment included rest, prolonged bathing, occupational therapy, good nutrition, exercise, and games. Charts describing the patients and their symptoms were given to the staffs who were then assigned the task of monitoring the patients. Another innovation was tracking patients who had been discharged. Records were maintained of these patients. Berkeley-Hill realized that in the absence of a formal psychiatric network, it would be difficult to look after discharged patients. Hill therefore supported the changes to the Indian Lunacy Act to make it possible for lunatic asylums to be called mental hospitals. Hill's theoretical writings are replete with clinical vignettes that demonstrate his presence of mind and a professional rigor that militates against the larger claim in this study that the mental health professionals were crudely complicit with the colonial project - though admittedly that was always a possibility if things were to go wrong with the psychiatric profession. Hartnack points out - on the basis of a particular patient with paranoid symptoms - that 'the psychoanalytic treatment of British patients in India thus turned out to be not a method of liberation, but rather yet another form of repression'. Even with the best of intentions, a few treatments will go wrong; it appears to me that both Hartnack's conclusions, and the severity of it, are not warranted by the evidence that she is able to offer in this study. It is of course important for a historian of colonial India to be on the lookout for instances when things might have gone wrong, or where there is a distinct possibility that it might go wrong. That is however not the same as maintaining that things did go wrong to the extent that she maintains on the basis of the clinical vignettes that have actually been assembled in this particular study.

\section{Conclusion}

A lot more research on this topic is necessary before it can be determined whether there were a sufficient number of instances when psychoanalysis could be shown to have colluded with the colonial agenda of the British Raj. Another important point that must be kept in mind is that the demographic representation of patients in Hill's clinic at Ranchi, like those of Bose in Calcutta, was not the same as that of Freud in Vienna, or most analysts in Europe. This pertains to the fact that most of the patients who presented themselves for treatment in Vienna were women whereas most of the British and Indian patients at Ranchi and Calcutta were men. My conjecture is that most Indian women were not allowed to present themselves in a psychiatric clinic because that would be difficult to do in a traditional patriarchal society. It is the absence of hysterics and the presence of the large number of obsessionals, psychotics, and phobics that made the Indian clinic different from European clinics. Any attempt therefore to draw a Freudian theory of subjectivity from an empirical base of patients is bound to be affected by these demographic differences - that is why there is no talk of hysteria in the Indian clinics whereas it must be the case that hysteria is as well demographically represented in the Indian population as anywhere else in the world. The clinical picture at Ranchi and Calcutta however does not represent a true picture of the demographic structure of mental health in the country at large. It would therefore be incorrect to generalize on the basis of the clinical data from just two Indian cities; a greater amount of anthropological data must be invoked in conjunction with clinical data in the Indian context to supplement the fact that 'observations gleaned directly from clinical psychotherapy reflect but a small, élite sample of a large heterogeneous population' (Kakar, 1981). This is however not to detract from the importance of Hartnack's study. I think we must however redefine Hartnack's study as an important exampleof how psychoanalysis was practiced in specific parts of the country, but resist the temptation of making links to the colonial project as a whole on the basis of onlythese meagre examples. This would be the case for the alleged forms of collusion between not only psychoanalysis and colonial forms of repression, but also between colonial anthropology and the colonial project. In the history of psychiatry, collusive forms of political repression in mental asylums, are known as 'false commitment' (Szasz, 1963, 1965). The propensity to overreact to such fears of collusion in the anthropology and psychoanalysis of the colonial era stems from conflating the differences between the terms 'aggressivity'and aggression', and in not identifying exactly how much empirical data would be necessary oradequate for different forms of historical representation. 


\section{References}

[1]. J. Lacan. The mirror stage as formative of the function of the I as revealed in psychoanalytic experience, Écrits: A selection, translated by A. Sheridan, edited by J.A. Miller (London: Tavistock/Routledge, 1949, 1977).1-7.

[2]. D. Evans. Dual relation, An introductory dictionary of Lacanian psychoanalysis (London and New York: Routledge, $1996 a)$, $49-50$.

[3]. J. Laplanche and J.B. Pontalis. Imaginary. The language of psychoanalysis, translated by D. Nicholson Smith (London: Karnac Books and the Institute of Psychoanalysis, 1973, 1988), 210.

[4]. A. Elliott. Psychoanalysis and social theory. The Blackwell companion to social theory, edited by B. S. Turner (Oxford, UK and Cambridge, USA: Blackwell, 1996), 171-193.

[5]. S. Pile. Freud, dreams, and imaginative geographies, Freud 2000, edited by A. Elliott (Cambridge: Polity Press, 1998$), 204-234$.

[6]. E.W. Said. Out of place: a memoir (New Delhi: Viking/Penguin Books, 1999).

[7]. S. Freud. Narcissism, On metapsychology: The theory of psychoanalysis, Vol. 11, (London: Penguin Books, 1914, 1991), 59-97.

[8]. D. E. Hall. The politics of identity: Lacan, Subjectivity (London: Routledge, 2004), 78-84.

[9]. G. Bose. The genesis and adjustment of the Oedipus wish, Vishnu on Freud's desk: A reader in psychoanalysis and Hinduism, edited by T.G.Vaidyanathan and J.J. Kripal (New Delhi: Oxford University Press, 1929, 1999), 21-38.

[10]. G. Bose. The beginnings of psychoanalysis in India: Bose-Freud correspondence (Calcutta: Indian Psychoanalytic Society, 1964, 1999).

[11]. R. Boyne. Structuralism. The Blackwell companion to social theory, edited by B.S. Turner (Oxford, UK and Cambridge, USA, Blackwell, 1996), 194-220.

[12]. C. Hartnack. Psychoanalysis in Bengal, Psychoanalysis in colonial India (New Delhi: Oxford University Press, 2001 a), 87-119.

[13]. E. Jones. Applications of psychoanalysis: Anthropology, What is psychoanalysis? (Greenwood Press, Westport, CT, 1948), 80-84.

[14]. A. Nandy. The savage Freud: The first non-western psychoanalyst and the politics of secret selves in colonial India, The savage Freud and other essays on possible and retrievable selves (Delhi: Oxford University Press, 1995a), 81-144.

[15]. T. Shalvey. Claude Lévi-Strauss, social psychotherapy, and the collective unconscious (New York: The Harvester Press, 1970).

[16]. A.K.Ramanujan. The Indian Oedipus, Vishnu on Freud's desk: A reader in psychoanalysis and Hinduism, edited by T.G.Vaidyanathan and J.J. Kripal (New Delhi: Oxford University Press, 1999), 109-136.

[17]. P.B. Courtright. Fathers and sons. Vishnu on Freud's desk: A reader in psychoanalysis and Hinduism, edited by T.G.Vaidyanathan and J.J. Kripal (New Delhi: Oxford University Press, 1999), 137-146.

[18]. G. Obeyesekere. Further steps in relativization: The Indian Oedipus revisited, Vishnu on Freud's desk: A reader in psychoanalysis and Hinduism, edited by T.G.Vaidyanathan and J.J. Kripal (New Delhi: Oxford University Press, 1999), $147-162$.

[19]. A. W. Johnson and D. P. Williams. Oedipus ubiquitous: The family complex in world literature (Stanford: Stanford University Press, 1996)

[20]. S. Freud. The horror of incest, The origins of religion, Penguin Freud Library, Vol.13, (London: Penguin Books, 1913a, 1990a), 5370.

[21]. R. LeVine. Psychoanalysis, Encyclopedia of cultural anthropology, edited by D. Levinson and M. Ember (New York: Henry Holt \& Company, 1996), Human Relations Area Files at Yale University, 1036-1042.

[22]. C. Lévi-Strauss. The problem of incest. The elementary structures of kinship, translated by J.H. Bell and J.R. von Sturmer, edited by R. Needham (Boston: Beacon Press, 1949, 1969), 12-25.

[23]. C. Geertz. The cerebral savage: On the work of Claude Lévi-Strauss, The interpretation of cultures: Selected essays by Clifford Geertz (New York: Basic Books, 1973), 345-359.

[24]. C. Hartnack. Psychoanalysis in colonial India (New Delhi: Oxford University Press, 2001b).

[25]. A. Elliott. The language of desire: Lacan and the specular structure of the self, Social theory and psychoanalysis in transition: Self and society from Freud to Kristeva (Oxford, UK and Cambridge, USA: Blackwell, 1992), 123-161.

[26]. C. Jenks. The centrality of theeye in Western culture: An introduction. Visual Culture (London and New York: Routledge, 1995), 125.

[27]. A. J. Mohamed. The economy of Manichean allegory, The post-colonial reader, edited by B. Ashcroft et al (London and New York: Routledge, 1995), 18-23.

[28]. D. Evans. Aggressivity, An introductory dictionary of Lacanian psychoanalysis (London and New York: Routledge, $1996 \mathrm{~b}), 6-7$.

[29]. B. B. Wolman (Editor). The psychoanalytic interpretation of history (New York and London: Basic Books, 1971).

[30]. M.S. Roth. Psychoanalysis as history: Negation and freedom in Freud (New Delhi: Oxford University Press, 1997).

[31]. E. Laclau. Emancipation(s), (London: Verso, 1996).

[32]. Y. Stavrakakis. Lacan and the political (London and New York, 1999).

[33]. J. Lacan. Aggressivity in psychoanalysis, Écrits: A selection, translated by A. Sheridan, edited by J.A. Miller (London: Tavistock/Routledge, 1948, 1977), 8-29.

[34]. K. Lorentz. On aggression (New York: Houghton Mifflin Harcourt, 1974).

[35]. E. Fromm. Escape from freedom (New York: Henry Holt \& Company, 1941, 1994).

[36]. J. Lacan. The Freudian unconscious and ours, The four fundamental concepts of psychoanalysis, translated by A. Sheridan, edited by J.A. Miller (London: Penguin Books, 1973a, 1997a), 13.

[37]. S. Kirschner. Normalization and its discontents, Where id was: Challenging normalization in psychoanalysis, edited by A. Molino and C. Ware (London and New York: Continuum Books, 2001), 14.

[38]. J.J. Goux. Oedipus, philosopher, translated by C. Porter (Stanford: Stanford University Press, 1994), Meridian: Crossing Aesthetics Series.

[39]. P. Goodrich. Oedipus Lex: Psychoanalysis, history, law (Berkeley and London: University of California Press, 1995).

[40]. S. Kakar. Clinical work and cultural imagination, The essential writings of Sudhir Kakar (New Delhi: Oxford University Press, 1995, 2001), 167-180.

[41]. A. Nandy. The savage Freud: The first non-western psychoanalyst and the politics of secret selves in colonial India, The savage Freud and other essays on possible and retrievable selves (Delhi: Oxford University Press, 1995b), 81-144.

[42]. S. Freud. Totem and taboo, The origins of religion, Penguin Freud Library, Vol.13, (London: Penguin Books, 1913b, 1990b), 43224.

[43]. C. Geertz. Being here: Whose life is it anyway? Works and lives: The anthropologist as author (Stanford: Stanford University Press, 1988a), 129-149.

[44]. C. Geertz. Being there: Anthropology and the scene of writing. Works and lives: The anthropologist as author (Stanford: Stanford University Press, 1988b), 1-24. 
[45]. J. Lacan. Of the Subject of Certainty. The four fundamental concepts of psychoanalysis, translated by J.A. Miller (London: Penguin Books, 1973b, 1997b), 33.

[46]. I. Kant. To perpetual peace: A philosophical sketch (1795). Perpetual peace and other essays, edited by Ted Humphrey (Cambridge: Hackett Publishing Company, 1983), 107-144.

[47]. A. Brook. Kant and Freud, available at: http://http-server.carleton.ca/ abrook/papers/2003-FreudKant-Psychoanalytic.pdf

[48]. J. Lacan. The neurotic's individual myth, translated by M.N.Evans, Psychoanalytic Quarterly, 48, 1953, 1979, pp. 405-425.

[49]. C. Lévi-Strauss. The anthropologist and the human condition. The view from afar, translated by J. Neugroschel and P. Hoss (Oxford: Basil Blackwell (1983, 1985), 25-36.

[50]. S. Freud. Totem and taboo, The origins of religion, Penguin Freud Library, Vol.13, (London: Penguin Books, 1913c, 1990c), 43224.

[51]. S. Kakar. Shamans, mystics and doctors: A psychological inquiry into India and its healing traditions (New Delhi: Oxford University Press, 1982, 1998).

[52]. F. Fanon. Black skin, white masks, translated by C.M. Markmann (New York: Grove, 1952, 1967).

[53]. H.L. Gates. Critical Fanonism, Critical Inquiry, 17, 1991, 457-470.

[54]. A. Nandy. The psychology of colonialism: Sex, age, and ideology in British India. The intimate enemy: Loss and recovery of self under colonialism (New Delhi: Oxford University Press, 1983), pp. 1-63, esp. 11-18.

[55]. P. Schimmel. Sigmund Freud's discovery of psychoanalysis: Conquistador and thinker (London and New York: Routledge, 2014), passim.

[56]. C. Hartnack. Psychoanalysis in colonial India (New Delhi: Oxford University Press, 2001c), 1.

[57]. S.K.Srinivasan. Freud in Sanskrit, Biblio: A Review of Books, 4: 5 \& 6, May-June, 1999, 8-10.

[58]. C. Hartnack. Vishnu on Freud's desk: Psychoanalysis in colonial India, Vishnu on Freud's desk: A reader in psychoanalysis and Hinduism, edited by T.G. Vaidyanathan and J. J. Kripal (New Delhi, 1999), 81-106.

[59]. W. B. Parsons. Freud's encounter with Hinduism: An historical-textual overview, Vishnu on Freud's desk: A reader in psychoanalysis and Hinduism, edited by T.G. Vaidyanathan and J.J. Kripal (New Delhi: Oxford University Press, 1999), 41-80.

[60]. F. Crews (Editor). Unauthorized Freud: Doubters confront a legend (New York: Penguin, 1998).

[61]. J. Forrester. Dispatches from the Freud wars: Psychoanalysis and its passions (Cambridge: Harvard University Press, 1997), 208248.

[62]. S. Kakar. Psychoanalysis and religious healing: Siblings or strangers? Journal of the American Academy of Religion 53:4, 1985, p. 846.

[63]. S. Kakar. The Guru as healer. Indian identity: Three studies in psychology (New Delhi: Penguin Books, 1996a), 160-176.

[64]. S. Kakar. Psychoanalysis and religion revisited, Indian identity: Three studies in psychology (New Delhi: Penguin Books, 1996b), 177-188.

[65]. S. Kakar. Empathy in psychoanalysis and spiritual healing. Mad and divine: Spirit and psyche in the modern world (New Delhi: Viking Penguin, 2008), 99-122.

[66]. S. Kakar and K. Kakar. The Indian mind. The Indians: Portrait of a people (New Delhi: Penguin Books, 2007), 180-203.

[67]. S. Kakar. The maternal-feminine in Indian psychoanalysis. The essential writings of Sudhir Kakar (New Delhi: Oxford University Press, 1989, 2001), 181-193.

[68]. S. Kakar. Introduction. The inner world: A psychoanalytic study of childhood and society in India (New Delhi: Oxford University Press, 1981), p.4.

[69]. T.S. Szasz. Law, liberty, and psychiatry: An inquiry into the social uses of mental health practices (New York: the Macmillan Company 1963, 1965), passim. 